\title{
The Vulnerable fishing cat Prionailurus viverrinus and other globally threatened species in Cambodia's coastal mangroves
}

\author{
Ret Thaung, Vanessa Herranz Muñoz, Jeremy Holden \\ Daniel Willcox and Nicholas J. Souter
}

\begin{abstract}
The Vulnerable fishing cat Prionailurus viverrinus faces a perilous future in South-east Asia. It was last sighted in Cambodia in 2003. We deployed 16 camera traps at four sites in southern Cambodia during January-May 2015 to determine if the fishing cat was still present in the country. Eight photograph/video captures of fishing cats were recorded from the mangroves in Peam Krasop Wildlife Sanctuary and one from Ream National Park, but there were no records from Botum Sakor National Park or Prey Nup. A number of other globally threatened species were also photographed in Peam Krasop Wildlife Sanctuary: the Sunda pangolin Manis javanica, the hog deer Axis porcinus and the large-spotted civet Viverra megaspila. We learnt of the killing of an alleged fishing cat at the Sanctuary in July 2015 in retaliation for raiding fishing nets. Illegal hunting and capture of fishing cats for the wildlife trade were reported by local informants at all sites. We provide photographic and video evidence of the fishing cats and highlight the importance of Cambodia's mangroves for threatened species conservation.
\end{abstract}

Keywords Cambodia, economic land concession, fishing cat, mangroves, Prionailurus viverrinus, South-east Asia

Supplementary material for this article is available at https://doi.org/10.1017/Soo30605317001491

The Vulnerable fishing cat Prionailurus viverrinus may be 1 approaching extinction in South-east Asia (Duckworth, 2016). There are few recent records from across the region (Mukherjee et al., 2016). Although this may be a result of

Ret Thaung ${ }^{\star}$ Centre for Biodiversity Conservation, Royal University of Phnom Penh, Cambodia

Vanessa Herranz Muñoz† Kla Trey | Cambodian Fishing Cat Project, Phnom Penh, Cambodia

Jeremy Holden 67 High Street, Mepershall, UK

Daniel Willcox 35 Rita Road, London, UK

Nicholas J. Souter $\dagger$ (Corresponding author) Fauna \& Flora International, Phnom Penh, Cambodia.

E-mail nicholas.souter@alumni.adelaide.edu.au

*Also at: Fauna \& Flora International, Phnom Penh, Cambodia

$\dagger$ Also at: Centre for Biodiversity Conservation, Royal University of Phnom Penh, Cambodia

Received 5 July 2017. Revision requested 12 September 2017.

Accepted 18 September 2017. First published online 27 November 2017. low survey effort, it does suggest that populations in these countries are either very small, plausibly extinct (e.g. Vietnam; Willcox et al., 2014) or entirely absent (e.g. Lao PDR; Mukherjee et al., 2016). A single camera-trap photograph of a fishing cat taken in 2003 in Kulen Promtep Wildlife Sanctuary (Rainey \& Kong, 2010) may be Cambodia's only previously confirmed record. Although there have been numerous unconfirmed claims (e.g. Royan, 2009), and captive fishing cats have been held in Phnom Tamao Zoo (Duckworth et al., 2005), their presence in other parts of the country cannot be verified. Cambodia retains large areas of potentially suitable wetland habitats similar to those used by fishing cats in other countries (e.g. Adhya, 2011; Cutter, 2015). These include marshes, swamps, tidal creeks, rice paddies and mangroves. Cambodia's coastal mangrove forests have not been exploited as heavily as in neighbouring countries (Marschke \& Nong, 2003), and mangroves are known to provide habitat for fishing cats in India (Mukherjee et al., 2012). With the aim of detecting fishing cats in Cambodia we deployed camera traps at four wetland sites covering a wide area in the south of the country, three within and adjacent to coastal mangroves and one in Botum Sakor National Park.

The four sites were chosen based on preliminary investigations and interviews with local people that indicated they may support fishing cats. All sites are either nationally or privately protected for conservation. Peam Krasop Wildlife Sanctuary $\left(246 \mathrm{~km}^{2}\right)$ is located near the Thai border in Koh Kong Province (Fig. 1) and overlaps the Koh Kapik and Associated Islets Ramsar Site (Marschke \& Nong, 2003). It is part of one of the best conserved mangrove forests in the Gulf of Thailand (Marschke \& Nong, 2003). The Sanctuary is adjacent to Botum Sakor National Park $\left(1,826 \mathrm{~km}^{2}\right)$, which is located on a peninsula along the south-west coast (Fig. 1), and comprises lowland evergreen and semi-evergreen broad-leaved forest, melaleuca forest, grassland, mangrove and patches of Oncosperma tigillarium palm. Botum Sakor National Park was the site of a suspected (Mukherjee et al., 2016) fishing cat record from 2008 (Royan, 2009). Ream National Park $\left(147 \mathrm{~km}^{2}\right)$ has extensive mangroves, with adjacent forests, mudflats and freshwater marshes (IUCN, 2003), and is bordered by Prey Nup to the south. At Prey Nup we surveyed a $10 \mathrm{~km}^{2}$ privately protected 


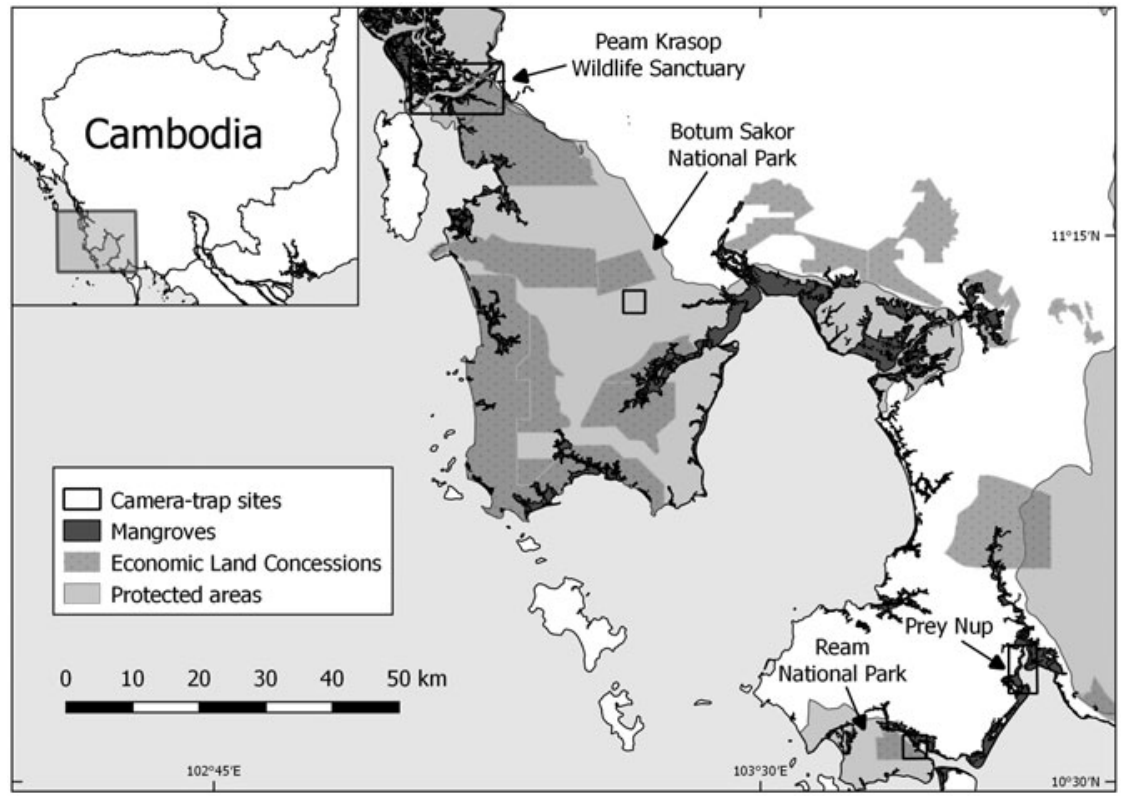

FIG. 1 Camera-trap locations in Peam Krasop Wildlife Sanctuary, Botum Sakor National Park, Ream National Park, and Prey Nup, in southern Cambodia.

TABLE 1 Details of camera-trap stations deployed at Peam Krasop Wildlife Sanctuary, Ream National Park, Prey Nup and Botum Sakor National Park in southern Cambodia (Fig. 1), with the number of trap-nights and a description of the habitat for each station.

\begin{tabular}{|c|c|c|c|}
\hline Camera-trap station & $\begin{array}{l}\text { Number of trap-nights } \\
\text { (deployment period) }\end{array}$ & Habitat description & Notes \\
\hline \multicolumn{4}{|c|}{ Peam Krasop Wildlife Sanctuary } \\
\hline 1 & 125 (21 Jan.-26 May 2015) & $\begin{array}{l}\text { A raised earth platform }(\mathrm{c} .3 \times 7 \mathrm{~m}) \text { adjacent to a c. } 10 \mathrm{~m} \\
\text { wide channel on a mangrove island }\end{array}$ & \\
\hline 2 & 125 (21 Jan.-26 May 2015) & $\begin{array}{l}\text { Mangrove forest inundated by up to } 5-10 \mathrm{~cm} \text { of water at } \\
\text { high tide }\end{array}$ & \\
\hline 3 & 125 (21 Jan.-26 May 2015) & $\begin{array}{l}\text { Path through non-inundated mangrove forest next to a } \\
100 \times 50 \mathrm{~m} \text { water hole }\end{array}$ & \\
\hline 4 & (21 Jan.-10 Apr. 2015) & Mangrove forest next to a narrow channel & $\begin{array}{l}\text { Camera } \\
\text { malfunctioned }\end{array}$ \\
\hline 5 & 125 (21 Jan.-26 May 2015) & Path through dry-land forest habitat adjacent to mangroves & \\
\hline 6 & (21 Jan.-26 May 2015) & Path through dry-land forest habitat adjacent to mangroves & Camera stolen \\
\hline \multicolumn{4}{|l|}{ Ream National Park } \\
\hline 7 & 71 (14 Mar.-24 May 2015) & Small water hole in mangrove forest & \\
\hline 8 & 71 (14 Mar.-24 May 2015) & Shallow $2 \mathrm{~m}$ wide channel in mangrove forest & \\
\hline 9 & 71 (14 Mar.-24 May 2015) & Elevated path through the mangrove forest & \\
\hline \multicolumn{4}{|l|}{ Prey Nup } \\
\hline 10 & 71 (13 Mar.-23 May 2015) & Mangrove forest, $50 \mathrm{~m}$ away from a main channel & \\
\hline 11 & 71 (13 Mar.-23 May 2015) & $\begin{array}{l}\text { Mangrove forest inundated by up to } 0.2 \mathrm{~m} \text { of water at } \\
\text { high tide }\end{array}$ & \\
\hline 12 & (13 Mar.-23 May 2015) & Mangrove forest $10 \mathrm{~m}$ away from a main channel & $\begin{array}{l}\text { Camera } \\
\text { malfunctioned }\end{array}$ \\
\hline \multicolumn{4}{|c|}{ Botum Sakor National Park } \\
\hline 13 & 111 (8 Feb.-30 May 2015) & Edge of a $40 \times 30 \mathrm{~m}$ waterhole in dry-land forest & \\
\hline 14 & 111 (8 Feb.-30 May 2015) & Edge of a $40 \times 30 \mathrm{~m}$ waterhole in dry-land forest & \\
\hline
\end{tabular}

mangrove forest that runs along the Kampong Smatj River, backed by rice paddies.

During January-May 2015 we deployed 16 8-megapixel Trophy Cam HD Hybrid Trail infra-red flash cameras (Bushnell Corporation, Overland Park, Kansas) in mangroves and adjacent freshwater wetlands and waterholes (known locally as trapeangs) at the four sites (Table 1). Camera-trap stations were selected following the advice of local people and park rangers. Fresh fish baits were staked in front of each camera trap. When a camera's 
TABLE 2 Medium-large bodied species recorded by camera traps in Peam Krasop Wildlife Sanctuary (six sites (two failed), 50o trap-nights), Ream National Park (five sites (one failed), 284 trap-nights), Prey Nup (two sites (one failed), 71 trap-nights) and Botum Sakor National Park (two sites, 222 trap-nights), in southern Cambodia (Fig. 1). Species are grouped according to their status on the IUCN Red List.

\begin{tabular}{|c|c|c|c|c|c|c|}
\hline Species & $\begin{array}{l}\text { Peam Krasop } \\
\text { Wildlife Sanctuary }\end{array}$ & $\begin{array}{l}\text { Ream } \\
\text { National } \\
\text { Park }\end{array}$ & $\begin{array}{l}\text { Prey } \\
\text { Nup }\end{array}$ & $\begin{array}{l}\text { Botum Sakor } \\
\text { National Park }\end{array}$ & Total & $\begin{array}{l}\text { Capture fre- } \\
\text { quency per } 100 \\
\text { trap-nights }\end{array}$ \\
\hline \multicolumn{7}{|l|}{ Critically Endangered } \\
\hline Sunda pangolin Manis javanica & 1 & & & & 1 & 0.09 \\
\hline \multicolumn{7}{|l|}{ Endangered } \\
\hline Hog deer Axis porcinus & 1 & & & & 1 & 0.09 \\
\hline Large-spotted civet Viverra megaspila & 22 & & & & 22 & 2.04 \\
\hline \multicolumn{7}{|l|}{ Vulnerable } \\
\hline Fishing cat Prionailurus viverrinus & 8 & 1 & & & 9 & 0.84 \\
\hline Lesser adjutant Leptoptilos javanicus & & & & 3 & 3 & 0.28 \\
\hline Sambar Rusa unicolor & 3 & & & 7 & 10 & 0.93 \\
\hline Smooth-coated otter Lutrogale perspicillata & 16 & & & & 16 & 1.49 \\
\hline Woolly-necked stork Ciconia episcopus & & 1 & & 1 & 2 & 0.19 \\
\hline \multicolumn{7}{|l|}{ Least Concern } \\
\hline Chinese pond-heron Ardeola bacchus & & 5 & 2 & 3 & 10 & 0.93 \\
\hline Collared kingfisher Todiramphus chloris & 1 & & & & 1 & 0.09 \\
\hline $\begin{array}{l}\text { Common palm civet Paradoxurus } \\
\text { hermaphroditus }\end{array}$ & 10 & 5 & 4 & 17 & 36 & 3.34 \\
\hline Common water monitor Varanus salvator & 10 & & & 1 & 11 & 1.02 \\
\hline Greater coucal Centropus sinensis & & 2 & 1 & & 3 & 0.28 \\
\hline Human Homo sapiens & 26 & 7 & 22 & 10 & 55 & 5.11 \\
\hline Leopard cat Prionailurus bengalensis & 8 & 1 & 3 & 1 & 13 & 1.21 \\
\hline Lesser mousedeer Tragulus kanchil & & & & 1 & 1 & 0.09 \\
\hline Little egret Egretta garzetta & & 16 & 7 & & 23 & 2.14 \\
\hline Long-tailed macaque Macaca fascicularis & 13 & & & & 13 & 1.21 \\
\hline Northern red muntjac Muntiacus vaginalis & & & & 2 & 2 & 0.19 \\
\hline Oriental magpie-robin Copsychus saularis & 18 & & & & 18 & 1.67 \\
\hline Red junglefowl Gallus gallus & & & & 6 & 6 & 0.56 \\
\hline Ruddy kingfisher Halcyon coromanda & & 8 & & & 8 & 0.74 \\
\hline Javan mongoose Herpestes javanicus & & 8 & 1 & & 9 & 0.84 \\
\hline $\begin{array}{l}\text { White-breasted waterhen Amaurornis } \\
\text { phoenicurus }\end{array}$ & 8 & & & & 8 & 0.74 \\
\hline \multicolumn{7}{|l|}{ Not Evaluated } \\
\hline Dog Canis familiaris & 14 & & 7 & 2 & 23 & 2.14 \\
\hline Species richness & 15 & 10 & 8 & 12 & 25 & \\
\hline No. of captures & 159 & 54 & 47 & 54 & 304 & \\
\hline
\end{tabular}

motion sensor was activated three photographs were taken consecutively, followed by a 6o-second video. The minimum gap between photograph/video captures was 1 hour. A capture therefore comprised any number of photographs and videos of the same individual, or individuals, taken within 1 hour of each other. Data on large and mediumsized mammals, birds and reptiles, including date, time and behaviour, were collated from camera-trap photographs and videos. Capture frequency was calculated as the number of captures per 100 trap-nights.

We recovered 13 cameras, deployed for a total of 1,077 trap-nights. Twenty-five species (14 mammals, 10 birds and one reptile), eight of which are categorized as threatened on the IUCN Red List (Table 2; Plate 1), were recorded from the four sites. Humans were the most frequently recorded, followed by the common palm civet Paradoxurus hermaphroditus and the little egret Egretta garzetta (Table 2). The largest number and greatest abundance of threatened species were recorded from Peam Krasop Wildlife Sanctuary, which also had the highest recorded species richness and total number of photograph captures. However, sites were not directly comparable because of differences in sampling effort, of which Peam Krasop had the highest (Table 1). Most of the people photographed were setting and collecting crab traps, fishing or collecting non-timber forest products, and many of them were accompanied by domestic dogs. Photographs/videos of fishing cats were recorded at station 1 in the Sanctuary on eight separate occasions (Plate 1). In the videos, cats were observed sniffing, licking and marking the ground (Supplementary 

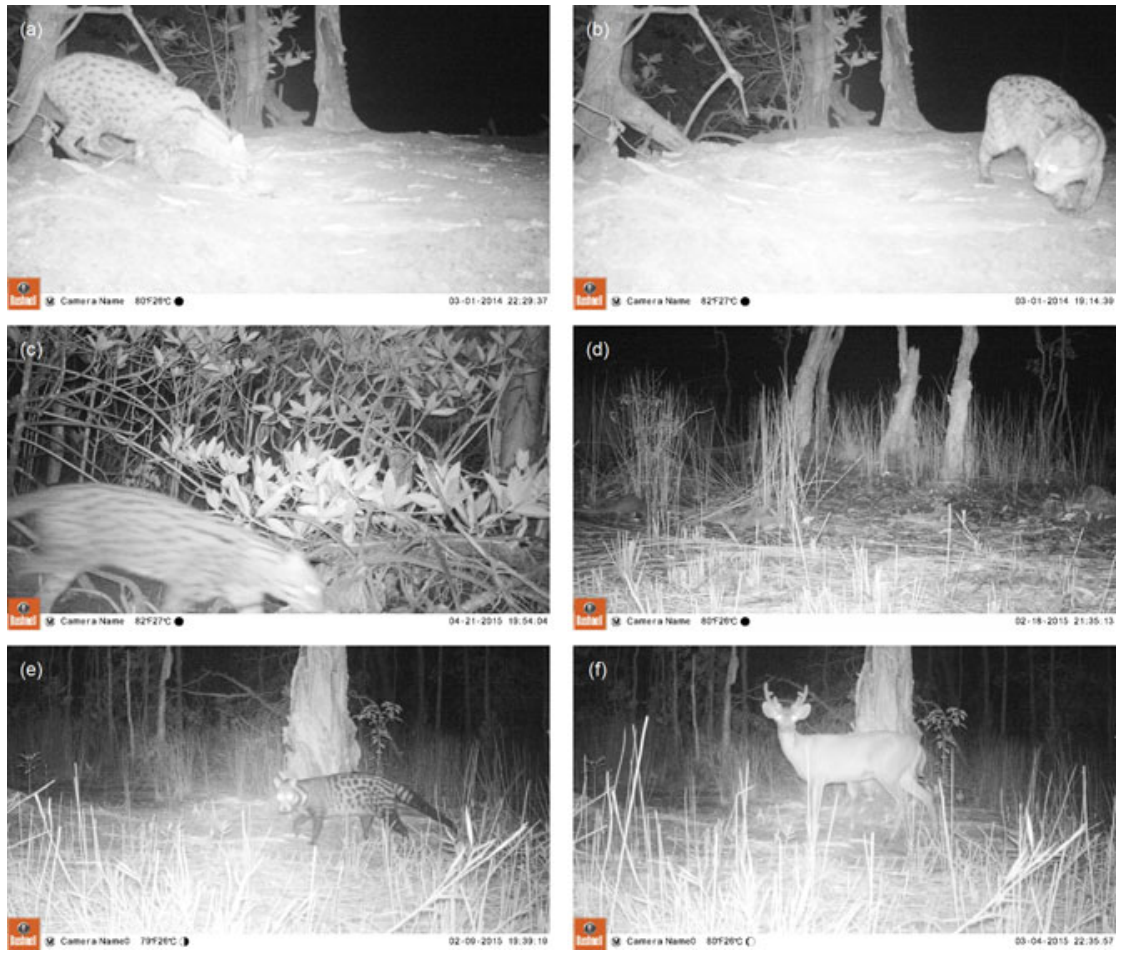

Plate 1 Camera-trap photographs of (a, b) fishing cat Prionailurus viverrinus, Peam Krasop Wildlife Sanctuary, (c) fishing cat, Ream National Park, and (d) Sunda pangolin Manis javanica, (e) large-spotted civet Viverra megaspila, and (f) hog deer Axis porcinus, in coastal mangroves of southern Cambodia.

Video S1) and defecating (Supplementary Video S2). One video showed a wet cat, apparently having emerged from the water (Supplementary Video $S_{3}$ ). A fishing cat was photographed at station 9 in Ream National Park (Plate 1). There were no records of fishing cats from either Prey Nup or Botum Sakor. Both trap stations that recorded the fishing cats were located in mangrove forests. The station at Peam Krasop was also visited by smooth-coated otters Lutrogale perspicillata, common water monitors Varanus salvator, long-tailed macaques Macaca fascicularis, and people and their domestic dogs (Table 2). The station at Ream National Park was also visited by a leopard cat Prionailurus bengalensis, common palm civets, Javan mongooses Herpestes javanicus and people.

As has occurred elsewhere (e.g. Mukherjee et al., 2012; Cutter, 2015), hunting and persecution are potential threats to fishing cats in coastal Cambodia. In July 2015 we received a report of an alleged fishing cat having been killed in Peam Krasop Wildlife Sanctuary by a local fisher in retaliation for raiding his nets. Although we could not confirm that the animal killed was a fishing cat, this indicates that mammalian predators are persecuted at this site. Local people at all sites reported that fishing cats, or morphologically similar species, have been persecuted and also captured for the wildlife trade.

Our photographs/videos confirm that fishing cats are still present in Cambodia, at two mangrove sites where they were previously unrecorded. In addition to the discovery of fishing cats we also recorded five other threatened species at Peam Krasop, highlighting the Sanctuary's importance for threatened species conservation. However, the Sanctuary was subjected to a much greater survey effort than the other sites, which were all home to a diversity of species and are thus also worthy of further conservation effort. Despite the threat posed by hunting and persecution our findings are encouraging, as our relatively modest survey effort yielded records of fishing cats and a number of other threatened species. Extensive surveys of Cambodia's mangroves are warranted, as they may be a stronghold for fishing cats and other threatened species.

\section{Acknowledgements}

We thank the Minister and the Head of General Administration of Nature Conservation and Protection from the Ministry of Environment, and the Department of Fisheries Administration of the Ministry of Agriculture, Forestry and Fisheries for permitting this research. We thank Rob Overtoom for allowing access to Prey Nup, and local rangers and authorities who assisted in the field. Chhin Sophea and Frederic Goes assisted with bird identification. Funding was generously provided to the Centre for Biodiversity Conservation at the Royal University of Phnom Penh by the Critical Ecosystem Partnership Fund.

\section{Author contributions}

All authors contributed to the study design, analysed camera-trap data and wrote the article. TR, VHM and JH undertook field work. TR, VHM and NJS summarized the camera-trap data. TR and NJS managed the programme, NJS obtained the funding. 


\section{References}

Adhy a, T. (2011) Status Survey of Fishing Cats (Prionailurus viverrinus) in Howrah and Hooghly, W. Bengal. Intermediate Report. Submitted to the small grants programme, WWF, India. Http://awsassets.wwfindia.org/downloads/status_survey_of_ fishing_cats.pdf [accessed 7 February 2017].

Cutter, P. (2015) Fishing cat ecology: food habits, home ranges, habitat use and mortality in a human-dominated landscape around Khao Sam Roi Yot, Peninsular Thailand. MS thesis. University of Minnesota, Twin Cities, USA.

Duckworth, J.W. (2016) Fishing cat in Southeast Asia: speculations on status. In Proceedings of the First International Fishing Cat Conservation Symposium, 25-29 November 2015, Nepal (eds A. Appel \& J.W. Duckworth), pp. 19-23. Fishing Cat Working Group, Bad Marienberg, Germany, and Saltford, Bristol, UK.

Duckworth, J.W., Poole, C.M., Tizard, R.J., Walston, J.L. \& Timmins, R.J. (2005) The jungle cat Felis chaus in Indochina: a threatened population of a widespread and adaptable species. Biodiversity and Conservation, 14, 1263-1280.

IUCN (2003) Ream National Park, Cambodia: balancing the local opportunity costs of wetland protection. Case studies in wetland valuation \#3. Https://cmsdata.iucn.org/downloads/ casestudyozream.pdf [accessed 7 July 2016].

Marschke, M. \& Nong, K. (2003) Adaptive co-management: lessons from coastal Cambodia. Canadian Journal of Development Studies, $24,369-383$.

Mukherjee, S., Adhya, T., Thatte, P. \& Ramakrishnan, U. (2012) Survey of the Fishing Cat Prionailurus viverrinus Bennett,
1833 (Carnivora: Felidae) and some aspects impacting its conservation in India. Journal of Threatened Taxa, 4, $33-55$.

Mukherjee, S., Appel, A., Duckworth, J.W., Sanderson, J., Dahal, S., Willcox, D.H.A. et al. (2016) Prionailurus viverrinus. In The IUCN Red List of Threatened Species 2016, e. T18150A50662615. Http://dx.doi.org/10.2305/IUCN.UK.2016-2. RLTS.T18150A50662615.en. [accessed 7 February 2017].

RAINEY, H.J. \& KonG, K. (2010) A fishing cat observation from northern Cambodia. CATnews, 52, 8-9.

Royan, A. (2009) Confirmation of the endangered fishing cat in Botum-Sakor National Park, Cambodia. CATnews, 51, 10-11.

Willcox, D.H., Phuong, T.Q., Duc, H.M. \& An, N.T.T. (2014). The decline of non-Panthera cat species in Vietnam. CATnews Special Issue, 8, 53-61.

\section{Biographical sketches}

Ret Thaung is a graduate of Fauna \& Flora International (FFI)'s MSc in Biodiversity Conservation at the Royal University of Phnom Penh. She is currently conducting applied conservation research on Asian elephants in Cambodia. Vanessa Herranz Muñoz is studying Cambodia's fishing cats. JeREmy HOLDen specializes in camera trapping rare and cryptic animals in South-east Asia. DANIEL WILLCOX has reviewed the status of fishing cats in Vietnam and has conducted field surveys of small carnivores in South-east Asia. Nicholas Souter specializes in research on threatened species, and managed FFI's University Capacity Building Project during 2013-2016. 